\begin{tabular}{|c|c|c|}
\hline & International Journal of Current Research in & \\
\hline & Biosciences and Plant Biology & \\
\hline $\begin{array}{l}\text { EXCELLENT } \\
\text { PUBLISHERS } \\
\end{array}$ & $\begin{array}{c}\text { ISSN: 2349-8080 (Online) } \bullet \text { Volume } 3 \bullet \text { Number } 1 \text { (January-2016) } \\
\text { Journal homepage: } \underline{\text { www.ijcrbp.com }}\end{array}$ & \\
\hline
\end{tabular}

Original Research Article

doi: http://dx.doi.org/10.20546/ijcrbp.2016.301.015

\title{
Antibacterial Activity of Leaf Extracts of Euphorbia heterophylla L. and Tamilnadia uliginosa (Retz.) Tirveng. \& Sastre against Xanthomonas campestris pv. citri
}

\author{
B. Kalpana ${ }^{1}$ and M. Prakash** \\ ${ }^{1}$ Research \& Development Centre, Bharathiar University, Coimbatore-641 046, Tamil Nadu, India \\ ${ }^{2}$ Department of Microbiology, Kanchi Shri Krishna College of Arts and Science, Kilambi, Kancheepuram-631 551, Tamil Nadu, \\ India \\ *Corresponding author.
}

\begin{abstract}
Acetone, ethanol, methanol and petroleum ether leaf extracts of the plants, Euphorbia heterophylla and Tamilnadia uliginosa were tested for their antibacterial activity against Xanthomonas campestris pv. citri using disc diffusion technique. The leaf extract concentrations tested were 0 (control), 125, 250, 500 and $1000 \mathrm{ppm}$ for each plant. The control $(0 \mathrm{ppm})$ received no extracts and chloramphenicol $(30 \mu \mathrm{g})$ was used as standard antibiotic. The antibacterial activity of the extracts used in the present study was found to be concentration dependent. The highest zone of inhibition, $2.8 \mathrm{~cm}$ was recorded in $1000 \mathrm{ppm}$ ethanolic leaf extract of Tamilnadia uliginosa with an activity index of 0.90 against Xanthomonas campestris pv. citri. At $125 \mathrm{ppm}$ concentration, ethanolic leaf extracts of Euphorbia heterophylla showed zone of inhibition $(0.8 \mathrm{~cm})$ and the other solvent extracts showed no activity. However, at $125 \mathrm{ppm}$ concentration, acetone, ethanol and methanol leaf extracts of Tamilnadia uliginosa showed least inhibition zones, 1.2 and $0.8 \mathrm{~cm}$ respectively.
\end{abstract}

\section{Article Info}

Accepted: 29 December 2015

Available Online: O6 January 2016

\section{Ke ywords}

Antibacterial activity

Citrus canker

Euphorbia heterophylla

Leaf extracts

Tamilnadia uliginosa

\section{Introduction}

Xanthomonas, a Gram negative bacterium, with its different species and varieties serve as causative agent of diseases in many plants. Among which the species, Xanthomonas campestris pv. citri causes citrus canker on most Citrus spp. (Graham, 2001; Gottwald et al., 2002; Das, 2003). Controlling of this pathogen is done by chemical methods worldwide as this disease in Citrus spp. causes considerable loss in plant growth and fruit yield (Graham et al., 2004).

As an alternate control measure, researchers also tried to control this disease using plant derived products and extracts. Leksomboon et al. (2001) tried aqueous extracts of five plant extracts of Hibiscus subdariffa Psidium guajava, Punica granatum, Spondias pinnata and Tamarindus indica for controlling citrus canker disease of Citrus aurantifolia (lime) caused by Xanthomonas axonopodis pv. citri under greenhouse condition and reported that a significant reduction in disease incidence. More than 200 plant diffusates have been tested against Xanthomonas campestris pv. citri by Akhtar et al. (1997) and reported that the diffusates from higher plants are possessing potential antimicrobial agents to be used against citrus canker. Similarly, the essential oils of 24 higher plants tested against Xanthomonas arboricola pv. juglandis causing walnut bacterial blight clearly showed that antibacterial activity against the bacterium (Soltani and Aliabdi, 2013). These studies clearly indicate that the plant derived products or extracts show promising results in controlling plant pathogenic 
bacteria, in particular Xanthomonas spp. In the present study, four different solvent extracts of leaves of Euphorbia heterophylla and Tamilnadia uliginosa against Xanthomonas campestris pv. citri using disc diffusion assay.

\section{Materials and methods}

The leaves of the medicinal plants selected for the present study were collected from Sirumalai hills (Eastern Ghats), Dindigul, Tamil Nadu and the identification was confirmed using standard local floras (Gamble and Fischer, 1957; Matthews, 1983). The names of the plants identified were Euphorbia heterophylla L. (Euphorbiaceae) and Tamilnadia uliginosa (Retz.) Tirveng. \& Sastre (Family: Rubiaceae) (Fig. 1). The leaves collected were transported to the laboratory for further processing. The cold extraction procedure was used for extracting leaves with solvents as per the procedure given below (Prakash and Karmegam, 2012; Vigneshwari et al., 2014). The leaves of the plants collected were individually washed with tap water, blotted with filter paper and spread over news paper for air drying under shade. After complete dryness, the leaves of individual plants were powdered using a mixer grinder. A known quantity of leaf powder $(100 \mathrm{~g})$ of each plant was taken in a $250 \mathrm{ml}$ conical flask and added with $100-200 \mathrm{ml}$ of acetone, ethanol, methanol and petroleum ether individually. The solvent-leaf powder mixtures were kept at room temperature for $48 \mathrm{hrs}$ and rapidly stirred using glass rod every $8 \mathrm{hrs}$. After $48 \mathrm{hrs}$, the extract of each plant was filtered through Whatmann No.1 filter paper to exclude the leaf powder. Then each filtrate was kept in beaker on a water bath at $45^{\circ} \mathrm{C}$ until the solvent gets evaporated. A greasy final material (crude extract) obtained for each plant was transferred to screw cap tubes and stored under refrigerated condition till use.
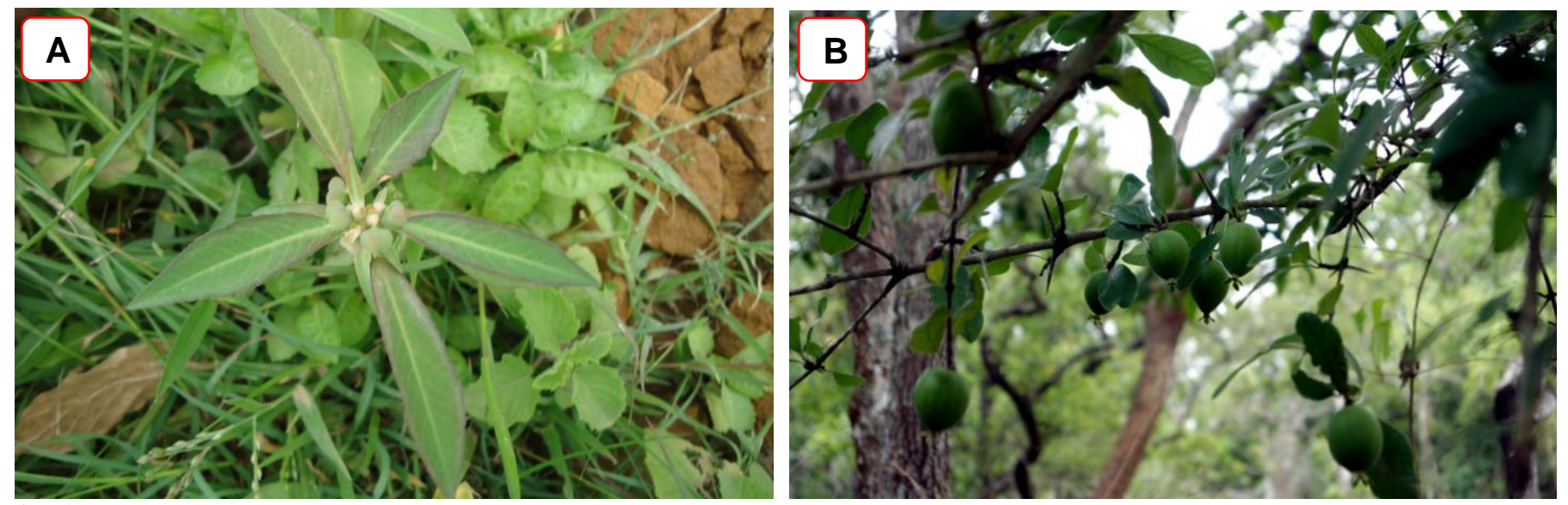

Fig. 1: The plants selected for the present study: (A) Euphorbia heterophylla; (B) Tamilnadia uliginosa.

By using digital electronic balance, $200 \mathrm{mg}$ of each crude extract was carefully taken in a standard measuring flask and $5 \mathrm{ml}$ of ethanol was added to dissolve the extract and 1-2 drops of emulsifier (Triton-X100) was added to completely dissolve the extract. Then it was made up to $200 \mathrm{ml}$ by adding distilled water. This forms the stock solution of $1000 \mathrm{ppm}$ (i.e., $1 \mathrm{mg} / \mathrm{ml}$ ), from which different concentrations of test solutions, 125, 250, 500 and $1000 \mathrm{ppm}$ were prepared and used for antibacterial assay. Disc diffusion method of antibacterial assay was used to test the sensitivity of selected test organisms to the ethanolic extracts individually and in combination as described above (Bauer et al., 1966).

The test bacteria, Xanthomonas campestris pv. citri maintained in the Laboratory of Department of Microbiology, Kanchi Shri Krishna College of Arts and
Science, Kilambi, Kanchipuram which was originally obtained from the Microbial Type Culture Collection (MTTC) of Institute of Microbial Technology (IMTECH), Chandigarh were used for the present study. The Petri plates of $100 \mathrm{~mm}$ diameter with Trypticase Soy Agar (TSA) were swabbed with broth culture of the test bacteria in separate plates by using sterile swab. Over this, prepared antimicrobial discs were placed under aseptic conditions. Three discs of each extract were placed in triangle. Chloramphenicol $(30 \mu \mathrm{g})$ was used as standard antibiotic. Also the discs without plant extract (discs prepared using $200 \mathrm{ml}$ distilled water $+5 \mathrm{ml}$ appropriate + one or two drops of emulsifier) were also maintained as control. The plates were then incubated at $37^{\circ} \mathrm{C}$ for $24 \mathrm{hrs}$ and the zone of inhibition (ZI) was measured in diameter $(\mathrm{cm})$ around the discs and recorded. The assays were performed with three 
replicates. From the results activity index was calculated by comparing the ZI of leaf extracts with standard antibiotic as follows:

$$
\text { Activity Index }=\frac{\text { Inhibition area of test sample }}{\text { Inhibition area of standard antibiotic }}
$$

\section{Results and discussion}

Antibacterial activity of leaf extracts of Euphorbia heterophylla and Tamilnadia uliginosa against Xanthomonas campestris pv. citri is shown in Table 1. The standard antibiotic, chloramphenicol $(30 \mu \mathrm{g})$ showed a zone of inhibition (ZI) of $3.1 \mathrm{~cm}$ against Xanthomonas campestris pv. citri. The four different solvent extracts of leaves of Euphorbia heterophylla and Tamilnadia uliginosa showed various degrees of antibacterial activity, no activity, ZI around the disc and ZI from $0.7-2.8 \mathrm{~cm}$.
Among the four different solvent extracts of Euphorbia heterophylla leaf extracts, ethanol extract showed higher activity than acetone, methanol and petroleum ether extracts. The $1000 \mathrm{ppm}$ ethanolic leaf extracts of Euphorbia heterophylla recorded $2.3 \mathrm{~cm} \mathrm{ZI,} \mathrm{followed} \mathrm{by}$ the same concentration of petroleum ether-leaf extract $(\mathrm{ZI}=1.9 \mathrm{~cm})$, methanol-leaf extract $(\mathrm{ZI}=1.7 \mathrm{~cm})$ and acetone-leaf extract $(\mathrm{ZI}=1.5 \mathrm{~cm})($ Table 1$)$.

The highest ZI of $2.8 \mathrm{~cm}$ was observed in $1000 \mathrm{ppm}$ ethanolic leaf extract of Tamilnadia uliginosa against Xanthomonas campestris pv. citri. The ethanolic leaf extract of Tamilnadia uliginosa showed antibacterial activity in all the extract concentrations, i.e., 125, 250, 500 and $1000 \mathrm{ppm}$ followed by methanolic leaf extract. Comparatively, Tamilnadia uliginosa leaf extracts showed higher activity than Euphorbia heterophylla leaf extracts (Table 1).

Table 1. Antibacterial activity of leaf extracts of Euphorbia heterophylla and Tamilnadia uliginosa against Xanthomonas campestris pv. citri.

\begin{tabular}{|c|c|c|c|c|c|c|c|}
\hline \multirow{2}{*}{ Plant leaves used } & \multirow{2}{*}{ Solvent } & \multicolumn{6}{|c|}{ Zone of inhibition $(\mathrm{cm})^{\#}$} \\
\hline & & Std.* & 0 ppm $\$$ & 125 ppm & 250 ppm & 500 ppm & 1000 ppm \\
\hline \multirow{3}{*}{$\begin{array}{l}\text { Euphorbia heterophylla L. } \\
\text { (Family: Euphorbiaceae) }\end{array}$} & Acetone & 3.1 & - & - & $\mathrm{AD}$ & 1.1 & 1.5 \\
\hline & Ethanol & 3.1 & - & 0.8 & 1.2 & 1.8 & 2.3 \\
\hline & Petroleum ether & 3.1 & - & - & 0.7 & 1.2 & 1.9 \\
\hline \multirow{2}{*}{$\begin{array}{l}\text { Tamilnadia uliginosa } \\
\text { (Retz.) Tirveng. \& } \\
\text { Sastre } \\
\text { (Family: Rubiaceae) }\end{array}$} & Acetone & 3.1 & - & $\mathrm{AD}$ & 0.8 & 1.4 & 2.0 \\
\hline & Petroleum ether & 3.1 & - & - & - & $\mathrm{AD}$ & 1.2 \\
\hline
\end{tabular}

\# - Values are mean of three replicates; ${ }^{\$}$ - Control (without extract); *Std. - Standard antibiotic, Chloramphenicol (30 $\mu$ g); AD Around the disc.

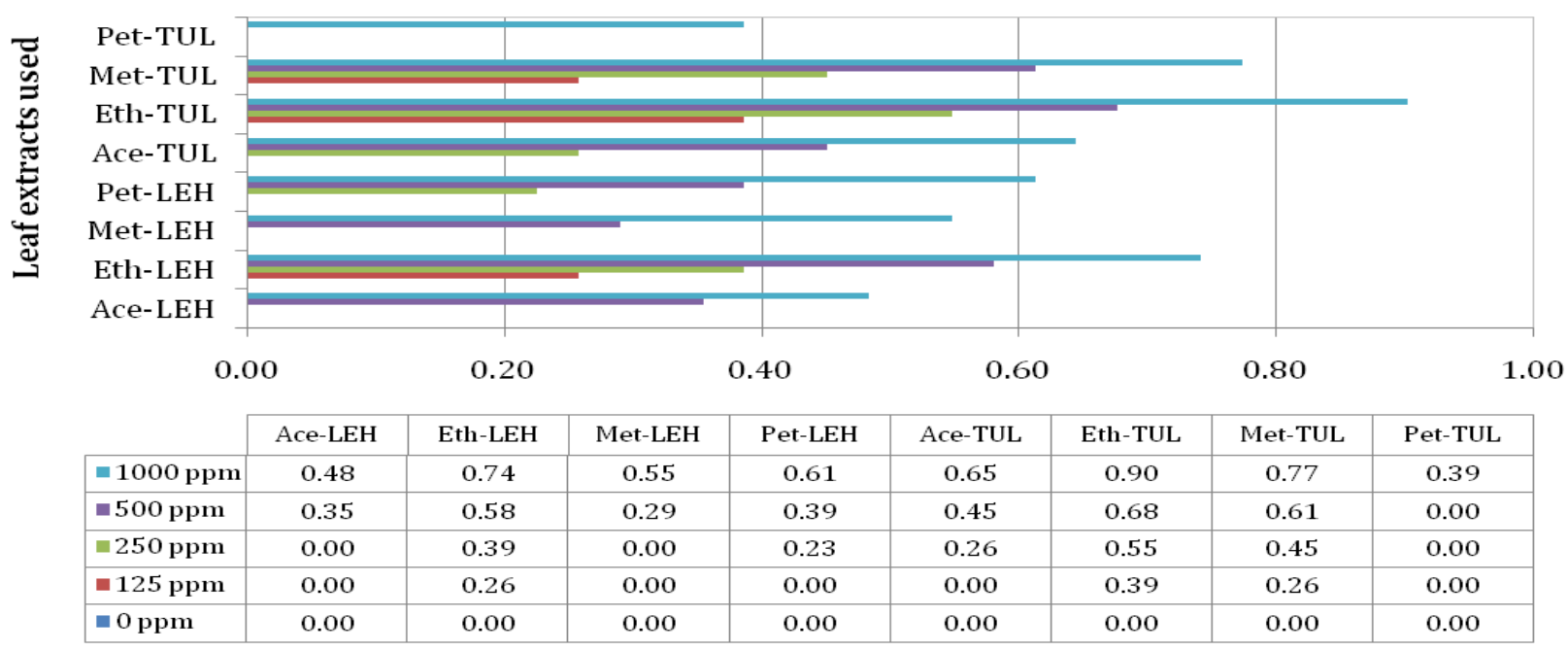

Activity Index

Fig. 2: Activity index of leaf extracts of Euphorbia heterophylla and Tamilnadia uliginosa against Xanthomonas campestris pv. citri (Standard antibiotic used-Chloramphenicol $30 \mu \mathrm{g}$; Ace-Acetone; Eth-Ehanol; Met-Methanol; Pet-Petroleum ether; LEH-Leaf extract of Euphorbia heterophylla; TUL-Leaf extract of Tamilnadia uliginosa). 
The ZI has been expressed in terms of activity index with reference to the standard antibiotic, chloramphenicol at $30 \mu \mathrm{g}$ (Fig. 2). A maximum activity index of 0.90 was found in $1000 \mathrm{ppm}$ ethanolic leaf extract of Tamilnadia uliginosa followed by the same concentration of methanolic extract of Tamilnadia uliginosa leaves>ethanolic extract of Euphorbia heterophylla leaves>acetone extract of Tamilnadia uliginosa leaves.

Studies conducted world-wide on the antibacterial activity of plant derivatives support the favourable and safety control of Xanthomonas spp. which fall in line with the present study findings. The citrus canker disease incidence in lime has reduced from $18-52 \%$ while applying aqueous extracts of Hibiscus subdariffa, Punica granatum, Spondias pinnata and Tamarindus indica (Leksomboon et al., 2001). The diffusates obtained from various parts of Phyllanthus emblica, Acacia nilotica, Sapindus mukorossi and Terminalia chebula exhibited the inhibition zone measuring 4.83-6.00 $\mathrm{mm}$ at $50 \mathrm{~g} / 1$ concentration has been reported by Akhtar et al. (1997) as most effective against Xanthomonas campestris pv. citri. Similarly, another species of Xanthomonas, Xanthomonas arboricola pv. juglandis was found to be effectively controlled by essential oils of Ziziphora persicae, Mentha piperita, Mentha spicata and Achillea vermiculatus in in vitro studies (Soltani and Aliabaadi, 2013). The present study findings indicate that there is a possibility of utilizing ethanolic extract of Euphorbia heterophylla and Tamilnadia uliginosa leaves for the control of Xanthomonas campestris pv. citri infection in citrus plants with proper field efficacy trials.

\section{Conflict of interest statement}

Authors declare that they have no conflict of interest.

\section{References}

Akhtar, M.A., Rahber-Bhatti, M.H., Aslam, M., 1997. Antibacterial activity of plant diffusate against Xanthomonas campestris pv. citri. Int. J. Pest Manage. 43(2), 149-153.

Bauer, A.W., Kirby, W.M.N., Sherris J.C., Turck, M., 1966. Antibiotic susceptibility testing by a standardized single disc method. Amer. J. Clin. Pathol. 45, 493-496.

Das, A.K., 2003. Citrus canker - A review. J. Appl. Hort. 5(1), 52-60.

Gamble, J.S., Fischer, C.E.C., 1957. Flora of the Presidency of Madras (Vols. I-III). Authority of Secretary of State for India in Council, London. 1389p.

Gottwald, T. R., Graham, J. H., and Schubert, T. S. 2002. Citrus canker: The pathogen and its impact. Online. Plant Health Progress. doi:10.1094/PHP-2002-0812-01-RV.

Graham, J.H., 2001. Varietal susceptibility to citrus canker: Observations from southern Brazil. Citrus Ind. 82(6), 15-17.

Graham, J.H., Gottwald, T. R., Cubero, J., Achor, D.S., 2004. Xanthomonas axonopodis pv. citri: factors affecting successful eradication of citrus canker. Mol. Plant Pathol. $5(1), 1-15$.

Leksomboon, C., Thaveechai, N., Kositratana, W., 2001. Potential of plant extracts for controlling citrus canker of lime. Kasetsart J. Nat. Sci. 35, 392-396.

Matthews, K.M., 1983. The Flora of Tamil Nadu Carnatic, St. Joseph's College, Tiruchirappalli, Tamil Nadu, India. 1034 p.

Prakash, M., Karmegam, N., 2012. In-vitro antibacterial activity of certain plant extracts against plant disease causing bacteria isolated from citrus plant. Int. J. Curr. Microbiol. App. Sci. 1(1), 1-11.

Soltani, J., Aliabadi, A.A., 2013. Antibacterial effects of several plant extracts and essential oils on Xanthomonas arboricola pv. juglandis in vitro. J. Essent. Oil Bear. Pl. 16(4), 461-468.

Vigneshwari, C., Nagaraj, R., Karmegam, N., 2014. Synergistic anti-Staphylococcus aureus (methicillin resistant) activity of ethnomedicinal plants from Shevaroy hills (Eastern Ghats), south India. Int. J. Curr. Res. Biosci. Plant Biol. 1(2), 51-59.

\section{How to cite this article:}

Kalpana, B., Prakash, M., 2016. Antibacterial activity of leaf extracts of Euphorbia heterophylla L. and Tamilnadia uliginosa (Retz.) Tirveng. \& Sastre against Xanthomonas campestris pv. citri. Int. J. Curr. Res. Biosci. Plant Biol. 3(1), 135-138. doi: http://dx.doi.org/10.20546/ijcrbp.2016.301.015 